\title{
A Fresh Start for Organic Farming Research
}

\author{
Thomas F. Döring \\ Faculty of Agriculture and Horticulture, Humboldt University of Berlin, Albrecht-Thaer-Weg 5, 14195 Berlin, \\ Germany; E-Mail: thomas.doering@agrar.hu-berlin.de
}

Submitted: 5 December 2013 | Published: 13 December 2013

\section{Welcome to Organic Farming, a New Open- Access Peer-Reviewed Journal!}

Over the past few decades the area of farmland under organic management has significantly and continuously increased [1]. This trend, observed across all continents, has been accompanied by a strong expansion of the market for organically produced goods, and a substantial increase of organic farming research efforts, funded through national and international programmes. At the same time, with the tremendous expansion of organic agriculture and food systems the organic sector has experienced a remarkable diversification and it is therefore essential to conduct research in, and find practical solutions for, an increasing diversity of organic farming systems across the globe.

Research findings from organic food and farming systems have had a significant impact on conventional agriculture, on agricultural policies and of course on the adaptation and optimisation of organic systems in practice [2]. However, organic ideas have not remained unchallenged: from the inception of organic farming research, there has been an intensive and dynamic controversy, both within and outside of academia, over the benefits of organic farming and food systems, and the potential and actual contributions of organic farming to the solution of global challenges such as food security [3-5], biodiversity conservation [6-8], and climate change [9]. It is likely that the years ahead will be no less dynamic, as organic food and farming systems will need to balance mounting economic pressures with organic principles and find their way between inspiring conventional agriculture and simultaneously competing with it.

With these past and expected future developments in mind it is clear that a solid research basis is needed for the progress of the organic sector and related areas. In fact, these thoughts highlight the pressing need to strengthen and expand the forum for research on organic farming. Thus, we are launching Organic Farming as new open-access peer reviewed journal to complement, enrich, and challenge current academic publishing in the area of organic food and farming systems. As the scientific community intensifies its efforts to solve global problems in agriculture and food systems, our journal will strive to facilitate this process, acting as an amplifier and focussing lens to highlight promising innovations and significant insights from organic farming research.

Following the spirit of the organic farming principle of fairness [10], all articles in this journal are free for readers, so as to decrease barriers to sharing knowledge. Publishing costs are met via membership fees paid by authors. This model is based on the idea that the community of contributing researchers jointly bears the costs of publishing; through this membership system [11] we offer a low-cost option to open-access publishing and hope to foster a close identification of contributing authors with the publishing process.

At the same time, establishing this new journal on organic farming offers a unique opportunity to shape the editorial process in a fresh and innovative way and to tackle the well-known problems associated with current academic publishing [12-14]. In particular, Organic 
Farming is committed to promoting and highlighting the impact of organic research in practice, alongside the promotion of traditional measures of visibility. We are dedicated to ensuring the highest quality standards through fast and rigorous peer review and editorial policies, and processes are designed to facilitate interand transdisciplinary exchange, e.g. by building bridges

\section{References}

1. Willer $\mathrm{H}$, Lernoud J. Organic Agriculture Worldwide: Key results from the FiBL-IFOAM survey on organic agriculture worldwide 2013. Available from: http://orgprints.org/22349/ (accessed on 6 December 2013). Frick, Switzerland, Research Institute of Organic Agriculture (FIBL); 2013.

2. Ekert $S$, Döring $T$, Häring $A M$, Lampkin $N$, Murphy-Bokern D, Otto K, Padel S, Vieweger A. Abschlussbericht zum Projekt 100E027-Evaluation des Bereichs Forschung und Entwicklung im Bundesprogramm Ökologischer Landbau. Report for Bundesanstalt für Landwirtschaft und Ernährung (German Federal Agency for Food and Agriculture). Available from: http://www.bundesprogramm.de/das-programm /evaluierung (accessed on 6 December 2013).

3. Seufert V, Ramankutty N, Foley JA. Comparing the yields of organic and conventional agriculture. Nature. 2012;485(7397):229-232.

4. Godfray HCJ, Beddington JR, Crute IR, Haddad L, Lawrence D, Muir JF, Muir JF, Pretty J, Robinson S, Thomas SM, Toulmin C. Food security: the challenge of feeding 9 billion people. Science. 2010;327 (5967):812-818.

5. Tomlinson I. Doubling food production to feed the 9 billion: a critical perspective on a key discourse of food security in the UK. Journal of Rural Studies. 2013;29:81-90.

6. Fuller $\mathrm{RJ}$, Norton $L R$, Feber $R E$, Johnson $\mathrm{PJ}$, Chamberlain DE, Joys AC, Mathews F, Stuart RC, between research on agricultural production on the one hand and food culture systems research on the other.

The members of the editorial board, with their shared enthusiasm for organic farming research, are committed to scientific quality and service to authors and readers. On behalf of the editorial board I would therefore like to invite you to submit articles to Organic Farming.

Townsend MC, Manley WJ, Wolfe MS, Macdonald DW, Firbank LG. Benefits of organic farming to biodiversity vary among taxa. Biology Letters. 2005;1(4):431-434.

7. Hodgson JA, Kunin WE, Thomas CD, Benton TG, Gabriel D. Comparing organic farming and land sparing: optimizing yield and butterfly populations at a landscape scale. Ecology Letters. 2010;13:1358-1367.

8. Gabriel D, Sait SM, Kunin WE, Benton TG. Food production vs. biodiversity: comparing organic and conventional agriculture. Journal of applied ecology. 2013;50:355-364.

9. El-Hage Scialabba N, Müller-Lindenlauf M. Organic agriculture and climate change. Renewable Agriculture and Food Systems. 2010;25(SI2):158-169.

10. IFOAM. The Principles of Organic Agriculture. Available from: http://www.ifoam.org/about_ifoam/ principles/ (accessed on 6 December 2013), 2005.

11. Librello Membership Program. Available from: http://www.librelloph.com/organicfarming/pages/view /membership (accessed on 6 December 2013).

12. Döring TF. Correspondence: Quality evaluation needs some better quality tools. Nature. 2007; 445:709.

13. Couchman JR. Peer review and reproducibility. Crisis or time for course correction? Journal of Histochemistry and Cytochemistry. 2013; doi: 10.1369/ 0022155413513462.

14. Pautasso M. Worsening file-drawer problem in the abstracts of natural, medical and social science databases. Scientometrics. 2010;85(1):193-202. 